\title{
The Art of Questioning in English Classroom in Junior Middle School
}

\author{
Xiaoling Yang \\ Foreign Language School, Nanchang Normal University, Nanchang Jiangxi 330030, China
}

\begin{abstract}
Questioning in English classroom plays a very important role in improving teaching quality. It is one of the most commonly used teaching methods in English classroom in junior middle school. It cannot only stimulate students to report clear answers, but also activate students' imagination and encourage their thinking. Therefore, how to question in the classroom teaching is of great practical significance. However, there are lots of problems: most of questions are ineffective; the ways of questioning are simple; the wait-time is too short and the questions are not prepared well; the feedback to the students is too general and the evaluation is not profound and teachers control the whole class and students have no right to ask questions. So teachers should focus on the effectiveness and skills of questioning to achieve teaching objectives and make questioning become an art. This article describes how to question from three aspects of ways of questioning, content of questioning and skills of questioning.
\end{abstract}

Index Terms - questioning, English classroom, effectiveness, art

\section{INTRODUCTION}

With the development of the reform in new teaching course, methods and teaching practice, more and more scholars do lots of research on classification of questions. According to Einstein (1994), raising a question is always more important than solving a question. There is also an old saying in China: Learning comes from thinking, which results from questioning. There is the closed relation between knowledge and questioning. If there is no questioning, knowledge will end.

Questioning in English classroom is an important part of English teaching and is one of the most frequently used teaching tools (Stern, 1983). It's also a good way to exchange information between teachers and students. Teachers can get information from students' answers, and then improve the teaching. Students also can express their thoughts about learning. The relationship between teachers and students will be well strengthened (Nunan, 2001). Questioning in English classroom is one of the most common forms of classroom interaction.

The questioning-centered classroom teaching has been regarded as one of the most effective means to stimulate students to learn. If teachers lack good design on the ways and skills of questioning, it'll decrease the effectiveness of questioning. Because of the role, questioning has become a kind of art. It requires many strategies to make questioning effective. Teachers should ask more effective questions and activate students to think and solve questions. This paper mainly states the strategies of questioning from many aspects in line with teaching experience.

\section{The CuRRENT Situation OF QUESTIONING}

Each question the teacher raised has its own function. In EFL classroom, most teachers often start a class with several questions and wan to review the content learned in the last lesson. Some of them usually ask questions at the transition of presenting old and new contents. Nowadays, there are a lot of problems in questioning in English classroom in junior middle school. Generally, questioning usually takes up too much of the whole class teaching. Teachers raise lots of questions most of which are not effective and closed and display questions. The answers are already known to students and many of them are simple yes/no questions. They ask questions not for achieving teaching aims but just for questioning. Some questions are even not related to the lesson at all. Some teachers get used to using questions to punish students who are not listening to the teacher.

The ways of questioning are simple. Teachers often call one student to answer. If he or she fails to answer the question, teacher will answer by himself or call another student. The other students in class cannot be involved in answering. In other word, they focus their attention on the other thing, but not the question. As a result, most students have few opportunities to participate the class and their ability of language communication cannot be well cultivated.

The wait-time is too short. After the teacher poses a question, the student is required to answer it within 1 second. Students do not have enough time to think about how to form the answers.

The questions are not prepared well. When teachers prepare the lesson, they usually do not take questions into account. So the teacher raises many ineffective questions in classroom. The time that teachers pose questions is not suitable. The questions occur to them in any time and they will ask students to answer them. They ask question, no matter whether the questions benefit the teaching and it's suitable to ask students questions.

The feedback to the students is too general and the evaluation is not profound. After students answer a question, most 
teachers usually praise students with "good", "well done", "excellent", "good job" and other words like that. To a certain extent, it may build up confidence for students. It's a pity that they lack detailed analysis and evaluation of students' answers after the praise. Some students may not know which is right in their answers or whether they are completely right. If things continue this way, students will think that the teacher's praise is merely formal. The enthusiasm of answering questions will be influenced. Some teachers get used to interrupting students' answer just because there are some mistakes about pronunciation and words and others. It's easy to cause psychological pressure for students.

Teachers control the whole class and students have no right to ask questions. The cramming education makes students have few opportunities to ask questions. The traditional class is teacher-centered, now it has changed a little, but only a little. Students in class are still passive receivers (Wang, 2016). They are so busy in answering teachers' questions that there is little time to think about asking questions.

\section{ThE ART OF QUESTIONING}

Questioning in English classroom is one of teaching techniques used frequently by teachers. It's also a kind of teaching art which has real influence over the whole classroom teaching. Teachers adjust and control the class, and students cooperate with teachers well through questioning (Wan, 2017). So questioning is considered as an art. Teachers want to make questions effective and they should focus on these aspects below: ways of questioning, content of questioning, skills of questioning.

\section{A. Ways of Questioning}

In order to enliven the English classroom, enrich the teaching contents, stimulate students' interest in learning and improve students' ability of communication, the way of teachers' questioning cannot be simple. Teachers should use various flexible ways of questioning.

Generally question is in some ways. Individual answer is to ask one of the students to answer by himself; group-discussion is that the group members discuss together, then one of them answers and the others in the same group can complement his answer; whole-discussion is that the whole class discuss the same question, express their own ideas, encourage and recruit each other and widen their trains of ideas. Teachers can also ask students to answer questions one by one in a group. Every student should get involved in answering questions, and then it can activate the teaching atmosphere. Different kinds of new, special and even creative opinions will be brought in a relaxed environment.

Sometimes teachers should create real situation, and make students participate in it. It's good for improving students' communication ability. For instance, after learning the key sentence "How much is it?". The teacher creates a real situation: the place is in a clothes store. One student plays as a customer, and the other is a shop assistant. They are talking about something. The teacher asks two students in a pair to make conversations and show them in front of the whole class.

When no one volunteers to answer questions, the teacher has to nominate students. They don't like nomination, for it can cause their tension and anxiety and when they don't raise their hands, it might mean that they don't prepare well enough. Sometimes to answer the questions by the whole class is also acceptable, by which everyone can participate in the class. As for teachers' self-answering, it is necessary when no one can make a perfect answer.

\section{B. Content of Questioning}

The content of questioning should be related to the content of teaching and it must be beneficial for achieving teaching aims. The questions should draw most students' attention and the content should be related to their daily life and times.

For instance, when students learn the new word "NBA", the teacher asks students to translate the sentence: Yao Ming is a basketball player of NBA. Most students are familiar with the sports star, so they will focus their attention on this sentence quickly.

Teachers' questions should face the whole students. If the teacher poses a question which is so difficult that nobody can answer it, the question will be meaningless for the English teaching. Teachers should learn about every student's abilities, levels, minds and characteristics. Then teachers can prepare questions which fit different students. Teachers need to choose different students to answer according to different content. For instance, easy questions are answered by less capable students and difficult ones are answered by more capable students. By this way, it can fully stimulate the students' initiative and cover the whole class.

\section{Skills of Questioning}

Every question raised by teachers must be effective and benefit for the teaching objectives. The teachers should learn skills about how to make questions effective.

\section{Preparation of questions}

Some teachers don't even prepare a set of questions carefully. They even don't know displaying questions and referential questions. And they never think when to ask displaying questions and when to ask referential questions. Some teachers care little about whether the questions they asked are related to the content that they are teaching. And 
these questions can make students puzzled. For many teachers, they don't think preparing for questions requires more effective than preparing for other kinds of teaching. Usually, questions are not planned at all. They usually pose a question which occurs to them spontaneously. Such ideas are wrong. It needs many efforts to plan questions, which is just like planning for other types of lessons.

For instance, when we learn a new lesson unit 3 How do you get to school?, teachers should prepare some questions: How do you get to school? How does he get to school? How long does it take to get to school? How far is it from your home to school? Teachers should predict the mistakes students will make when they answer these questions. For example, they may not tell the difference between "how far" and "how long" and the use of "by bus" and "take the bus" will confuse them. When teachers prepare the questions, they should predict the content of students' answers, and suppose the mistakes students may make in their answers. According to this, teachers design a set of solving scheme.

\section{Wait-time}

Wait-time is an important factor in English classroom questioning. To make students involve in the classroom activities is the purpose of teacher's questioning. It is clear that wait-time can trigger students' participation and improve their communicative ability. That is something that teachers should not forget. Students always complain about not giving enough time for them to finish their answers. As it is known that the time in class is limited, teachers cannot wait too long for the students to give answers.

Teachers should give different wait-time according to the types of questions. They will give longer wait-time after giving the students referential questions and higher-level questions than after giving displaying questions and low level questions. That is because the former ones usually need more time for students to think or form their opinions.

If the students cannot answer the questions immediately, teachers ought to wait for a while and can also give some hints to make the students succeed in answering the questions.

The length of wait-time will affect students' answers. The question according to $2 \mathrm{~b}$ of section B of book 7B "Why do you think their dream will come true?" is posed. The teacher asks one student to answer it and gives the student around 30 seconds to think it. The student presents the answer: Because they will work hard to build a bridge. The same question is raised in another class. The teacher nominates a student almost in the same level with that student. The wait-time given is about 1 minute and the student's answer is "Because they hope to have a bridge. Where there is a will, there is a way and maybe the government will build a bridge for them". Apparently, the length of wait-time should be longer for students to answer referential questions. The longer wait-time teacher gives, the better answers students present.

Now that wait-time plays an important role in promoting students' responses, teachers should pay special attention to the use of it in teaching. Slowing down and making a pause longer between questions and answers should be useful.

\section{Feedback of questioning}

Feedback can either be positive or negative. Most teachers agree that positive feedback is very useful, and they usually repeat students' responses, which usually means that their responses are excellent. After students answer the questions, it's good for teachers to give right feedback properly. The feedback should be encouraged, for it can build up confidence for students and activate them to answer next question. Sometimes they can use gestures or eye-gazing as an encouraging way. The students may feel relaxed and be more confident to answer questions.

A lesson "Do you have a soccer ball?" is studied in a middle school. When the teacher asks students to finish 1a in section A, a student is asked to answer it and he or she doesn't know the Chinese meaning of "volleyball". The teacher poses the gesture of playing volleyball with smile. Then the student speaks out the right answer immediately.

While effective feedback is not always positive. If it is necessary, teachers should provide error-correction. Students have to know what the mistake exists.

After students answer questions, the teachers can also get students' feedback how much they have learned and whether they have completely mastered the teaching contents. Teachers can adjust teaching strategies according to the feedback, and then achieve the teaching objectives.

When we learn unit $6 \mathrm{I}$ 'm Watching TV, the teacher asks students to answer questions according to the pictures in $3 \mathrm{a}$ "What's the boy doing?", a student's answer is "He doing his homework". Apparently, the student doesn't master present progressive tense. The teacher gets important feedback from students' responses. Thus the teacher focuses on the teaching of tense and asks students practice more key sentences. Therefore, the feedback of questioning is very important either for students or teachers.

\section{Relationship between teachers and students}

It is very important to build up a good relationship with students. Junior middle school students are still very young, they are adolescences, and they are pretty emotional. That is because they mostly act according to what they feel rather than what they think. Therefore, if they like the teacher, they will like the teacher's lesson, they will like to answer questions in class and pay more attention on the teacher's questions, just because they also hope that their action can catch teacher's eye. But if they don't like the teacher, they will not answer questions even sometimes they know the answer and some even quit the subject.

A real example can prove the importance of relationship between teachers and students. A student is punished in English classroom for his or her violation of class rules. After that, the student has psychological inversion in English classroom and loses the interest in learning English. However, after the teacher communicates with the student for many 
times, the student becomes active in English class and high on answering teacher's questions. So the teacher should communicate with students frequently and get to know their viewpoints better after class. This is an important way of building up good relationship between teachers and students.

\section{The StRategIES OF QUESTIONING}

The traditional class is teacher-centered, now it has changed a little. The education ideal is taking teachers as the leaders and students as the cores. The students are participants in English classroom, and they should be given more opportunities to ask questions. Students should be positive in answering questions and asking questions. Then it forms an environment of student-centered questions.

\section{A. Providing Equal Opportunities}

Teachers always focus their questions on the active students or excellent students or students in front row in the real teaching classroom. As a consequence, it will discourage students to participate in answering questions. If things continue this way, what's worse is that they will develop an idea that the teacher will not nominate them. They will ignore teachers' questions, and some students even think they are bystanders and wait for other students' responses.

Both teachers and students think that everyone in class should be given equal chances to participate in answering questions. If active students occupy the class, there will be many more students losing interest in learning English, and they may feel teachers are not caring about them. After the teachers raise a question, they should run their eyes over the whole class and make sure that every student can get the opportunity to answer the question. Students can enjoy the success and the ability of thinking can be well cultivated.

In most cases, it is not necessary to nominate students, and then they can ask students to answer questions one by one, pair by pair, row by row, group by group or the whole class answer questions together. If so, more students can get involved in answering questions and make every student have opportunity to answer questions. For instance, when we learn 1a of section A in unit 6 I'm Watching TV., students are required to match the activities with the pictures within 1 minute. After they finish it, the teacher asks students in a row to answer questions one by one. Students read these phrases and match them with the pictures, then translate them.

1. watching $\mathrm{TV}$

2. cleaning

3. reading a newspaper

4. talking on the phone

5. listening to a $\mathrm{CD}$

6. using the computer

7. making soup

8. washes the dishes

9. exercising

Students answer the questions actively and they are willing to answer questions. Thus students who are less active in class can get involved in the activity. If teachers nominate active students frequently, the other students will ignore teacher's questions, and they will focus on other things. Therefore, teachers should provide equal opportunities for the whole students to reach the goal of questioning.

\section{B. Encouraging Students' Questioning}

Generally teachers raise questions and students answer them. Students hardly ask questions to their teachers or other students in classroom. They are afraid of being laughed at if their question is very easy to be answered by other students. They also think it is hard and they do not know what to ask and how to ask. Sometimes, they are not brave enough to ask the teacher for help and there are not always chances for them to conduct question as well. Teachers also think the time is limited.

Asking questions by students is important and useful for learning English. If someone has doubts on the contents or other students' answers, they should ask questions to the teacher or the students in classroom. Teacher should offer opportunities for students to ask questions and encourage them to ask question. Students are the cores in English classroom. They should ask more questions actively and let teachers know what they are confused about.

The teachers need to encourage them to raise more questions and cultivate their ability to think. If things go on like this, they will develop the habit of asking questions voluntarily. To a certain degree, asking the peers questions may be more effective. For instance, students can be divided into groups. Students in one group can ask student in other groups who is required to be the first one to answer them. Then the teacher takes down how many questions the groups have answered and which group will be the champion group, and then praise the students in champion group in front of the whole students.

It is an effective way to foster students' interest in learning English for middle school students through questioning in a competitive game. For instance, when we learn the conversation in $2 \mathrm{~d}$ in unit 2 section A of book 7B Go For It!, we choose one group to design questions. The questions are as follow:

(1)When dose Scott work? 
(2)What time does Scott have breakfast?

(3)What time dose Scott exercise?

(4)Is Scott usually late for work?

The students in other group are required to answer the questions, and the teacher will call the students who raise their hands immediately. In this way, students will be interested in questioning in English classroom.

\section{CONCLUSION}

As a second language, English is a tool of communication and questioning in English classroom is a means of communication between teachers and students. So it is of great importance to learn English through asking questions in English classroom. The study explores some questioning skills about English teaching in junior middle school from these aspects: preparation of questions, wait-time, feedback and relationship between teachers and students. There are many strategies to be researched to make questioning become an art. Teachers should focus on the design of questions and guide students to raise effective questions by themselves.

It is proved that questioning in English classroom in junior middle school plays an important role and is an art as well as a teaching method. It's also one of the most fundamental and important forms used to create activities between teachers and students.

Questioning can help teachers get information from students and adjust the process and design of teaching. When a class has gone on for a long time and students feel tired about the teaching, questioning at this time plays an important role of drawing students' attention and livening up atmosphere in the class. By the end of a class, questions are commonly used to summarize the key points presented in the lesson. Questions can strengthen the relationship between teachers and students and let students active. It helps to achieve the teaching aims. In the long term, students may make it habit to think and cultivate students' innovative thinking. Questioning plays an essential role in EFL classroom. Therefore, it's necessary for teachers to pose effective questions.

Teachers should know more about the current situation on questioning in English classroom and avoid raising useless questions. In the long run, it is very helpful to improve teachers' professional skills. There are more strategies of questioning to be researched to make questions effective. It means a lot for us to explore and research more.

\section{ACKNOWLEDGEMENTS}

This paper is funded by 11531 project of Nanchang Normal University

\section{REFERENCES}

[1] Einstein, R. (1994). The Study of Second Language Acquisition. Oxford: Oxford University Press.

[2] Nunan, D. (2001). Language Teaching Methodology: A textbook for Teachers. New York: Prentice Hall.

[3] Qiang Wang. (2016). A Course in English Language Teaching, Second Edition. Beijing: Higher Education Press.

[4] Stern, H. H. (1983). Fundamental concepts of language teaching. Oxford: Oxford University Press.

[5] XiuLei Wan.(2017). The Research on Effectiveness and Strategy of Classroom Questioning. Lanzhou: North West Normal University.

Xiaoling Yang was born in Nanchang, China in 1970. She received master degree in linguistics from East China Technology University, China in 2005.

She is currently professor in the School of Foreign Language, Nanchang Normal University, Nanchang, China. Her research interests include English Teaching and Cross-culture. Prof. Yang is a member of Jiangxi Association of English. 